\title{
Hyperventilation Therapy for Control of Posttraumatic Intracranial Hypertension
}

\author{
Daniel Agustín Godoy ${ }^{1,2 *}$, Ali Seifi ${ }^{3}$, David Garza ${ }^{4}$, Santiago Lubillo-Montenegro ${ }^{5}$ \\ and Francisco Murillo-Cabezas ${ }^{6}$
}

${ }^{1}$ Neurointensive Care Unit, Sanatorio Pasteur, San Fernando del Valle de Catamarca, Argentina, ${ }^{2}$ Intensive Care Unit, Hospital San Juan Bautista, Catamarca, Argentina, ${ }^{3}$ University of Texas Health Science Center San Antonio, San Antonio, TX, United States, ${ }^{4}$ Department of Neurosurgery, University of Texas Health Science Center San Antonio, San Antonio, TX, United States, ${ }^{5}$ Intensive Care Unit, Hospital Universitario $N^{a} S^{a}$ de Candelaria, Santa Cruz de Tenerife, Spain, ${ }^{6}$ Intensive Care Unit, Hospital Universitario Virgen del Rocío, Sevilla, Spain

OPEN ACCESS

Edited by: Fernando Testai, University of Illinois at Chicago, United States

Reviewed by:

Benjamin Aaron Emanuel, Keck School of Medicine of

USC, United States

Minjee Kim

Northwestern University Feinberg

School of Medicine, United States Baback Arshi,

University of llinois at Chicago, United States

*Correspondence:

Daniel Agustín Godoy dagodoytorres@yahoo.com.ar

Specialty section:

This article was submitted to Neurocritical and Neurohospitalist

Care, a section of the journal

Frontiers in Neurology

Received: 06 March 2017 Accepted: 19 May 2017 Published: 17 July 2017

Citation:

Godoy DA, Seifi A, Garza D, Lubillo-Montenegro $S$ and Murillo-Cabezas F (2017)

Hyperventilation Therapy for Control of Posttraumatic Intracranial Hypertension.

Front. Neurol. 8:250.

doi: 10.3389/fneur.2017.00250
During traumatic brain injury, intracranial hypertension (ICH) can become a life-threatening condition if it is not managed quickly and adequately. Physicians use therapeutic hyperventilation to reduce elevated intracranial pressure (ICP) by manipulating autoregulatory functions connected to cerebrovascular $\mathrm{CO}_{2}$ reactivity. Inducing hypocapnia via hyperventilation reduces the partial pressure of arterial carbon dioxide $\left(\mathrm{PaCO}_{2}\right)$, which incites vasoconstriction in the cerebral resistance arterioles. This constriction decrease cerebral blood flow, which reduces cerebral blood volume and, ultimately, decreases the patient's ICP. The effects of therapeutic hyperventilation (HV) are transient, but the risks accompanying these changes in cerebral and systemic physiology must be carefully considered before the treatment can be deemed advisable. The most prominent criticism of this approach is the cited possibility of developing cerebral ischemia and tissue hypoxia. While it is true that certain measures, such as cerebral oxygenation monitoring, are needed to mitigate these dangerous conditions, using available evidence of potential poor outcomes associated with HV as justification to dismiss the implementation of therapeutic $\mathrm{HV}$ is debatable and remains a controversial subject among physicians. This review highlights various issues surrounding the use of $\mathrm{HV}$ as a means of controlling posttraumatic $\mathrm{ICH}$, including indications for treatment, potential risks, and benefits, and a discussion of what techniques can be implemented to avoid adverse complications.

Keywords: hyperventilation, intracranial hypertension, intracranial pressure, hypocapnia, cerebral ischemia, cerebral hypoxia, severe traumatic brain injury

\section{INTRODUCTION}

Physicians started to explore hyperventilation (HV) as a way to lower cerebral blood volume (CBV) during the 1920s (1). One of the earliest documented descriptions of this treatment dates back to 1959, when Lundberg reported the use of HV to reduce increased levels of intracranial pressure (ICP) (2). HV induces arteriolar vasoconstriction, which results in decreased cerebral blood flow (CBF) and, consequently, a decrease in CBV (3-5). As time went on, this easily implemented therapy was widely used for the management of intracranial hypertension (ICH) secondary to severe traumatic brain injury (sTBI) (6-8). By the mid-1990s, in neurosurgical centers located within the United 
States and the United Kingdom, the rate of HV utilization was 83 and $97 \%$, respectively $(6,7)$. A European database analysis released in 2008 indicated that during the first $24 \mathrm{~h}$ after insult, physicians employed prophylactic $\mathrm{HV}$ in more than half of their TBI cases (9).

Although HV rapidly and effectively reduces ICP, the effects are transient and have not been associated with the improvement of final patient outcome $(10,11)$. Because HV can potentially trigger secondary cerebral ischemic lesions and create adverse repercussions that affect other organ systems, and the therapy remains a topic of controversy and vigorous debate $(10,11)$. Available evidence indicates that intense or prolonged prophylactic $\mathrm{HV}$ is detrimental and should be avoided, especially during the acute phase of sTBI; however, the therapy is still recommended as a way to temporarily manage life-threatening elevations of ICP (12). The goal of this review is to provide an update that evaluates the current studies describing HV for ICP control to determine if $\mathrm{HV}$ has a role in the management of acute brain injury.

\section{$\mathrm{CO}_{2}$ PHYSIOLOGY: BASIC CONCEPTS}

Hyperventilation leads to an increase in alveolar ventilation (AV) $(13,14)$, the volume of air per minute that enters the respiratory zones (bronchioles, alveoli, etc.) that is also available for gas exchange (13). Because a portion of that volume remains in areas where gases do not diffuse into the bloodstream, AV can be determined by the following equation (13):

$$
\mathrm{AV}=\mathrm{RR}(\text { respiratory rate }) \times\left(\begin{array}{l}
\mathrm{VT}[\text { volume tidal }]- \\
\mathrm{VDS}[\text { volume dead space }]
\end{array}\right) .
$$

Alveolar ventilation has an inverse relationship with the alveolar $\mathrm{CO}_{2}$ level; when $\mathrm{AV}$ increases, the alveolar $\mathrm{CO}_{2}$ levels decrease $(13,14)$. However, alveolar $\mathrm{CO}_{2}$ has a direct association with the partial pressure of arterial $\mathrm{CO}_{2}\left(\mathrm{PaCO}_{2}\right)$, which reflects the balance between the production and elimination of $\mathrm{CO}_{2}(13,14)$ :

$$
\mathrm{PaCO}_{2}=\mathrm{CO}_{2} \text { production }-\mathrm{CO}_{2} \text { elimination. }
$$

A patient's cellular production of $\mathrm{CO}_{2}$ is dependent on several variables, including diet, exercise, temperature, and hormone activity (thyroid) (13). $\mathrm{CO}_{2}$ production remains relatively stable and constant, except during severe hypermetabolic states. If $\mathrm{CO}_{2}$ transport and cardiac output remain unchanged, $\mathrm{PaCO}_{2}$ levels will be determined inversely by the rate of $\mathrm{CO}_{2}$ elimination through the AV (13).

$\mathrm{CO}_{2}$ is a soluble and diffusible gas that is transported in three different ways: $10-15 \%$ of it is dissolved according to the $\mathrm{PaCO}_{2}$ (Henry's Law); $20-30 \%$ of it is bound to plasma proteins and hemoglobin that form carbaminic complexes, and $65-70 \%$ of it is converted to bicarbonate/carbonic acid in the red blood cells and plasma (13). This third complex reaction helps maintain equilibrium between bicarbonate $\left(\mathrm{HCO}_{3}^{-}\right)$and hydrogen $\left(\mathrm{H}^{+}\right)$ ions $(13,14)$ (Figure 1).

Normal $\mathrm{PaCO}_{2}$ values fluctuate between 35 and $45 \mathrm{mmHg}$ (4.7-6 kPa) at normal body temperature and at a sea level with barometric pressure of $760 \mathrm{mmHg}(13,14)$.
If body temperature decreases, the solubility of $\mathrm{CO}_{2}$ increases and $\mathrm{PaCO}_{2}$, consequently, decreases $(13,15) . \mathrm{PaCO}_{2}$ decreases $4.5 \%$ for each centigrade degree temperature decrease. The opposite occurs when temperature increases (Table 1) (15). At higher altitude, the barometric pressure decreases, stimulating AV, so normal $\mathrm{PaCO}_{2}$ levels are lower (Table 2) (16-20).

\section{CHANGES IN CEREBRAL PHYSIOLOGY DURING $\mathrm{PaCO}_{2}$ REDUCTION}

The brain is one of the most metabolically active organs in the entire body. Because it lacks reserves of oxygen and glucose, two nutrients that are vital to maintaining vigorous physiochemical activity, it is important for the brain to have some system of continuous delivery through which these substrates can be received (21). This delivery system occurs through the $\mathrm{CBF}$. CBF is so crucial that the brain has developed adaptive mechanisms to maintain adequate and constant flow despite changes in physiological variables or metabolic requirements (21-23). The maintenance of CBF is called "cerebral autoregulation," and it is primarily achieved by the resistance arterioles $(22,23)$. By dilating or contracting in response to changes in arterial blood pressure, viscosity, gases, and metabolic demands, the arterioles can regulate $\mathrm{CBF}(22,23)$.

\section{CEREBRAL BLOOD FLOW}

" $\mathrm{CO}_{2}$ reactivity" is the ability cerebral resistance arterioles possess to dilate or contract in response to changes in the partial pressure of arterial $\mathrm{CO}_{2}$. Dilation occurs when the partial pressure of arterial $\mathrm{CO}_{2}$ increases $\left(\mathrm{PaCO}_{2}>44 \mathrm{mmHg}\right.$ indicates hypercapnia); the vessels contract if the $\mathrm{PaCO}_{2}$ level decreases $\left(\mathrm{PaCO}_{2}<35 \mathrm{mmHg}\right.$ indicates hypocapnia) $(3-5,10,11)$. However, this vascular activity only occurs within the $20-60 \mathrm{mmHg}$ range of $\mathrm{PaCO}_{2}$ (24). The diameter of the vessels will not change if $\mathrm{PaCO}_{2}$ levels rise above or drop below that specific range. Because of these restrictions, when it is plotted on a graph, the autoregulatory curve depicting $\mathrm{CBF}$ according to shifting $\mathrm{PaCO}_{2}$ resembles a sigmoid function (Figure 2) $(4,25)$.

Changes in vessel diameter elicited by hypocapnia compared to those elicited by hypercapnia are not proportional (5). If the $\mathrm{PaCO}_{2}$ increases to $80 \mathrm{mmHg}$, vasodilation will increase CBF by $100-200 \%$, causing a release of catecholamines and an increase of metabolic activity. On the other hand, for every millimeter of mercury that the $\mathrm{PaCO}_{2}$ decreases, the CBF will decrease by $3 \%$; thus, $\mathrm{PaCO}_{2}$ levels between 20 and $25 \mathrm{mmHg}$ are associated with a $\mathrm{CBF}$ reduction of $40-50 \%(5,24)$.

The pial arterioles responsible for these instances of dilation and contraction are less than $50 \mu \mathrm{m}$ in diameter. The vascular endothelium reacts to changes in $\mathrm{pH}$ that occur within the perivascular space by releasing mediators that regulate the endothelium and vascular smooth muscle $(5,26)$. These vasoactive factors are thought to include nitric oxide, prostaglandins, cyclic nucleotides, potassium, and calcium (5).

Cerebral blood flow is not normally homogeneous; it varies according to the metabolic rate and activity of each region (27). 


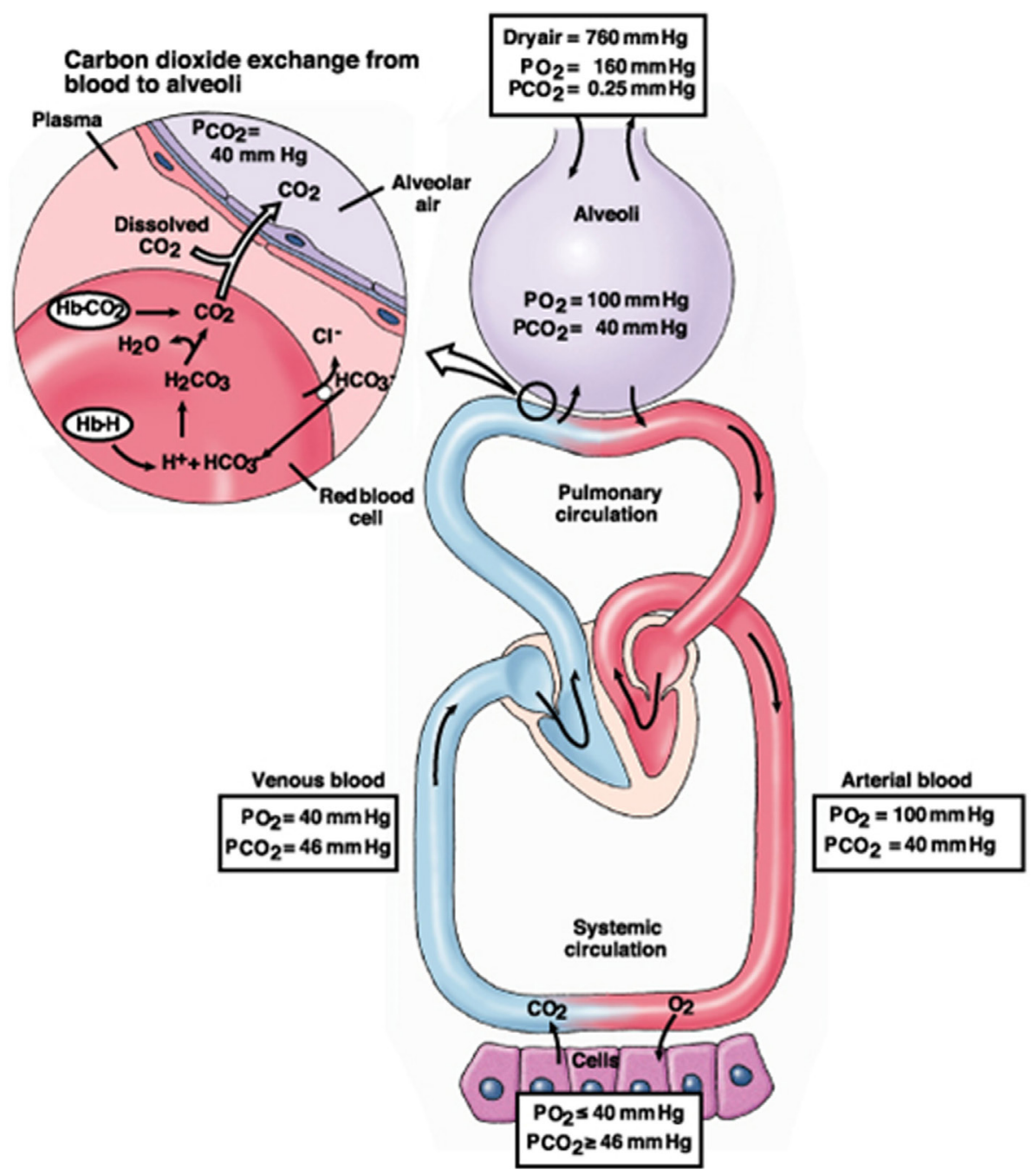

FIGURE 1 | The $\mathrm{CO}_{2}$ physiology from cells to alveoli.

TABLE 1 | Modification of normal $\mathrm{PaCO}_{2}$ values according to changes in central temperature ([ref]15).

\begin{tabular}{lcc}
\hline Temperature $\left({ }^{\circ} \mathbf{C}\right)$ & $\mathbf{p H}$ & $\mathbf{P a C O}_{\mathbf{~}}(\mathbf{m m H g})$ \\
\hline 40 & 7.36 & 46.2 \\
39 & 7.37 & 44.1 \\
38 & 7.39 & 42 \\
37 & 7.40 & 40 \\
36 & 7.41 & 38.1 \\
35 & 7.43 & 36.3 \\
34 & 7.44 & 34.6 \\
33 & 7.46 & 33 \\
32 & 7.47 & 31.4 \\
31 & 7.49 & 29.9 \\
30 & 7.5 & 28.5 \\
\hline
\end{tabular}

Cerebrovascular reactivity to $\mathrm{CO}_{2}$ can also vary, depending on location or circumstance (28). During sTBI, especially during the first few hours, $\mathrm{CO}_{2}$ reactivity is exacerbated, especially in areas that are adjacent to contusions or subdural hematomas (29-32).
TABLE 2 | The normal $\mathrm{PaCO}_{2}$ according to altitude and barometric pressure.

\begin{tabular}{lccc}
\hline City (country) & $\begin{array}{c}\text { Altitude above } \\
\text { sea level }(\mathbf{m})\end{array}$ & $\begin{array}{c}\text { Barometric } \\
\text { pressure } \\
\text { (mmHg) }\end{array}$ & $\begin{array}{c}\text { Normal PaCO } \\
\text { (mmHg) }\end{array}$ \\
\hline Sea Level (13) & 0 & 760 & 38.3 \\
Colima (Mexico) (16) & 494 & 717 & 37.1 \\
Cordoba (Mexico) (16) & 927 & 681.4 & 36 \\
Orizaba (Mexico) (16) & 1,248 & 656.1 & 35.2 \\
Leon (Mexico) (16) & 1,804 & 614.5 & 33.8 \\
Puebla (Mexico) (16) & 2,144 & 590.3 & 32.9 \\
Mexico City (16) & 2,238 & 583.8 & 32.7 \\
Toluca (Mexico) (16) & 2,651 & 556.1 & 31.7 \\
Bogota (Colombia) (17) & 2,640 & 560 & 31.2 \\
Quito (Ecuador) (18) & 2,850 & 543 & 31.6 \\
Cusco (Peru) (19) & 3,350 & 530 & 30.6 \\
La Paz (Bolivia) (20) & 3,577 & 496 & 30 \\
\hline
\end{tabular}

For these reasons, changes in normal levels of $\mathrm{CO}_{2}$ are potentially dangerous secondary insults that can drastically impact brain physiology (11). 


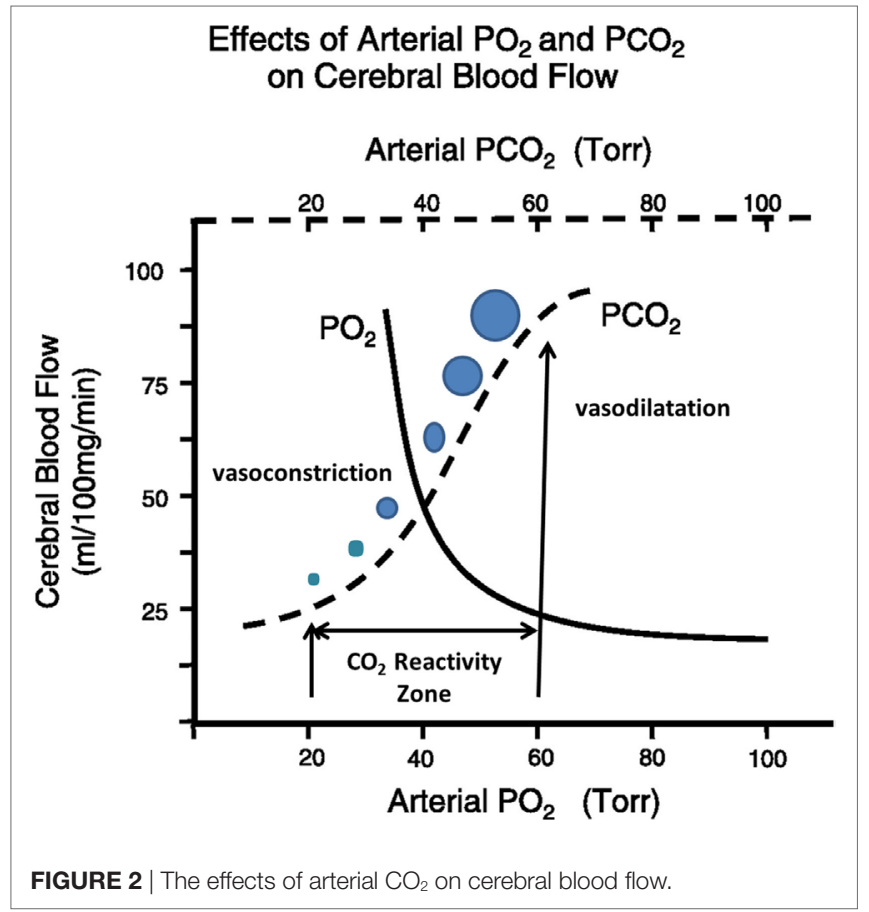

\section{CEREBRAL BLOOD VOLUME}

In adult humans, normal CBV is 3-4 $\mathrm{ml}$ per $100 \mathrm{~g}$ of parenchymal tissue (5). Although changes in the diameter of the cerebral blood vessels might alter the total CBV, $70 \%$ of the total blood volume contained in the brain corresponds to the venous system $(33,34)$. Because veins and capillaries do not react to fluctuations in $\mathrm{PaCO}_{2}$, any changes in the CBV following incidents of hypercapnia or hypocapnia can be attributed only to changes in the arterial blood volume $(33,34)$. It has been estimated that $\mathrm{HV}$ reduces CBV by approximately $0.049 \mathrm{ml} / 100 \mathrm{~g}$ per millimeter of mercury $\mathrm{CO}_{2}$ reduction (5). If only $30 \%$ of the total CBV is located in the arteries and only pial vessels respond to changes in $\mathrm{PaCO}_{2}$, a hypocapnia-induced $\mathrm{CBF}$ decrease of $30 \%$ will only result in a CBV decrease of 7\% (35). In this manner, a pronounced decrease in $\mathrm{CO}_{2}$ can create a substantial decrease in CBF, but has little effect on the corresponding CBV and ICP (35). It has been suggested that the CBV response to hypocapnia is further diminished during arterial hypotension, specifically when the mean arterial blood pressure (MABP) range is reduced from 154 to $114 \mathrm{Hg}$ (5).

\section{INTRACRANIAL PRESSURE}

In accordance with the Monro-Kellie hypothesis, alterations in the CBV will create ICP changes only after spatial compensatory mechanisms are exhausted $(10,11,14)$. These compensatory mechanisms include changes in cerebrospinal fluid (CSF) and blood volume principally through increased venous return to the heart and deviation of CSF to the spinal channel. Hypercapnia triggers vasodilation, which leads to an increase in CBV and a subsequent increase in ICP; hypocapnia triggers vasoconstriction, which leads to a decrease in $\mathrm{CBV}$ and a subsequent decrease in ICP $(10,11,14)$. HV is a therapy that uses the conditions of hypocapnia to trigger vasoconstriction within the resistance arterioles in the cerebral parenchyma in order to reduce ICP. Doing this modifies the absolute value and morphology of the ICP pulse wave by decreasing the P2 (tidal wave) component (36).

\section{BRAIN METABOLISM}

Hypocapnia increases cerebral metabolic activity through various mechanisms. It induces the release of excitatory amino acids ( $N$-Methyl-D-aspartate and glutamate) and increases neuronal excitability, glucose consumption, and the metabolic rate of $\mathrm{O}_{2}$ $\left(\mathrm{CMRO}_{2}\right)(11,14)$. It also potentiates and prolongs convulsive activity $(11,14)$.

\section{CEREBRAL OXYGENATION}

Hypoxia occurs when the body or a specific region of the body does not receive or is unable to process an adequate amount of oxygen to meet its metabolic demands (37-39). Tissular hypoxia can be local or global, but both variants can be detected using bedside cerebral monitoring that measures either the tissular pressure of $\mathrm{O}_{2}\left(\mathrm{ptiO}_{2}\right)$ or the venous saturation of $\mathrm{O}_{2}$ in the bulb of the jugular vein $\left(\mathrm{SvjO}_{2}\right)(40)$. There are four different pathways through which hypocapnia can cause or contribute to tissular hypoxia (37-39):

- Vasoconstriction brought upon by hypocapnia can cause a reduction in $\mathrm{CBF}$, resulting in "ischemic hypoxia" $(3,5,10$, $11,14)$.

- A reduction in carbon dioxide levels can impair gas exchange in the lungs, triggering "hypoxemic hypoxia" $(10,11)$.

- The oxygen-hemoglobin (Hgb) dissociation curve can shift to the left as a result of hypocapnia, which increases the Hgb's affinity for $\mathrm{O}_{2}$ and hinders the release of $\mathrm{O}_{2}$ into the cells which is also known as "high affinity hypoxia" $(10,11)$.

- Heightened neuronal excitability and cerebral metabolism brought upon by hypocapnia increases metabolic needs, resulting in hypoxia $(11,14)$.

The various changes that hypocapnia induces with regard to cerebral physiology are depicted in Figure 3.

\section{THE SYSTEMIC EFFECTS OF HYPOCAPNIA}

Induced hypocapnia affects all organ systems $(10,11,14)$. When evaluating hypocapnia for the purposes of potentially administering therapeutic HV, one should also take into account the effects of mechanical ventilation $(10,11,41,42)$. Because patients suffering from sTBI might concomitantly present contused lesions in the lung parenchyma, microaspirations of gastric content, or acute respiratory distress syndrome (ARDS), they may require protective ventilation with low VT and high levels of positive end-expiratory pressure (PEEP) (10, 11, 41, 42). Therapeutic HV 


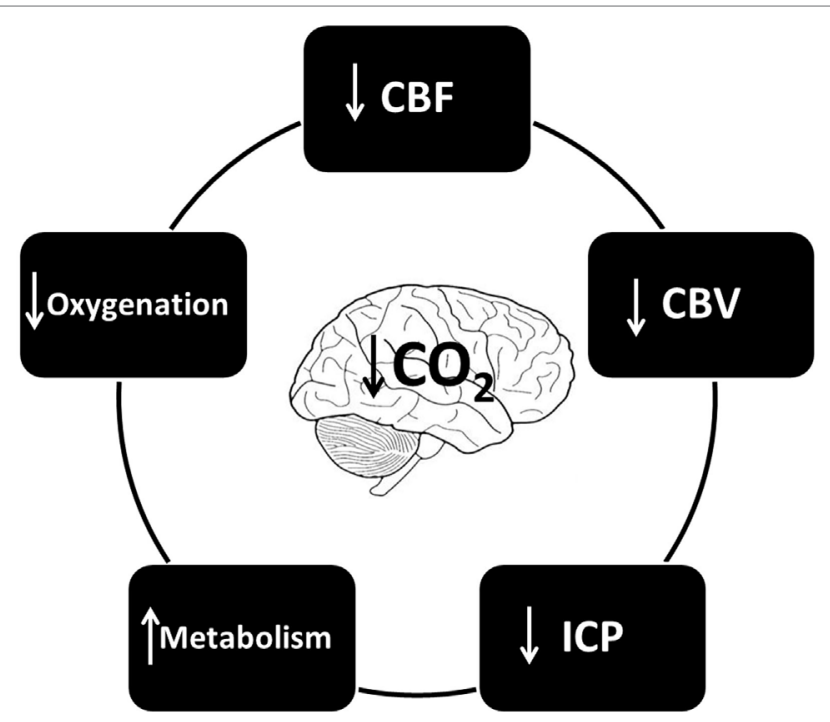

FIGURE 3 | The cerebral effects of hypocapnia.

is achieved by increasing the RR or VT. Increasing the VT can be detrimental because of the stress it places on the body; it induces alveolar stretching, which causes cytokine release and inflammation both locally and systemically (10, 11, 41-43).

Hypocapnia decreases blood perfusion to renal tissue, gastrointestinal tissue, and skin and skeletal muscle tissue; it also provokes an increase in adhesion and platelet aggregation $(10,11,14)$. Low $\mathrm{PaCO}_{2}$ levels incite bronchoconstriction, attenuate hypoxic pulmonary vasoconstriction, inhibit the production of surfactant, and increase the permeability of the alveolo-capillary membrane and upper airways $(11,14)$. Several variables can compromise gas exchange and increase a patient's susceptibility to infections. These include: atelectasis, edema, reduced compliance, pulmonary defense mechanism alterations, ventilation-perfusion ratio alterations, and changes to the shunt fraction $(11,14)$. Respiratory alkalosis (a disturbance in the acid/base balance associated with decreased levels of potassium, calcium, and phosphate in plasma) complicates tissue oxygenation by shifting the $\mathrm{O}_{2} / \mathrm{Hgb}$ dissociation curve to the left $(10,11)$.

Hypocapnia-induced vasoconstriction compromises coronary blood flow and increases the risk of coronary spasm. It also increases myocardial metabolic demands, which may increase a patient's risk for myocardial ischemia. This is especially true if the patient has predisposing factors or a history of heart disease $(10,11,14)$. Hypocapnia also promotes reperfusion injury and encourages the development of arrhythmias, specifically, atrial fibrillation (11).

\section{HYPOCAPNIA AND NEUROTOXICITY}

Low levels of $\mathrm{PaCO}_{2}$ produce neurotoxic effects by inducing the release of cytotoxic excitatory amino acids, increasing dopamine levels in the basal ganglia, and promoting the incorporation of choline into the phospholipids of cell membranes (44-46).

\section{HYPERVENTILATION AND TIMING RESTRICTIONS}

Cerebral arteriolar reactivity to $\mathrm{CO}_{2}$ is dependent on perivascular pH changes (26). HV induces hypocapnic alkalosis, which rapidly triggers buffer mechanisms that attempt to normalize changes made to extracellular space and (CSF) levels $(10,11)$. During this time, there is a rapid cellular efflux of hydrogen ions $\left(\mathrm{H}^{+}\right)$that bind to bicarbonate $\left(\mathrm{HCO}_{3}^{-}\right)$and generate carbonic acid $\left(\mathrm{H}_{2} \mathrm{CO}_{3}\right)$, which dissociates in water $\left(\mathrm{H}_{2} \mathrm{O}\right)$ and $\mathrm{CO}_{2}(10,11)$. At the same time, extracellular bicarbonate is exchanged with chloride from the intracellular space $(10,11)$. These buffer mechanisms are inefficient because they rapidly deplete; if hypocapnia persists, alkalosis will perpetuate.

A slower but more efficient buffer occurs at the proximal renal tubular level, where $\mathrm{HCO}_{3}^{-}$reabsorption is inhibited at the same time $\mathrm{H}^{+}$secretion is stimulated $(10,11)$. These reactions begin minutes after hypocapnic alkalosis originates and are maintained for hours or even days, allowing the CSF and perivascular $\mathrm{pH}$ to normalize $6 \mathrm{~h}$ after hypocapnia begins; HV naturally becomes less effective after this buffer pathway becomes activated $(10,11)$. Clinical studies have demonstrated a $40 \%$ decrease in $\mathrm{CBF}$ when $\mathrm{PaCO}_{2}$ levels are $20 \mathrm{mmHg}$; but, after $4 \mathrm{~h}$ of $\mathrm{HV}, \mathrm{CBF}$ begins to normalize (47). $\mathrm{CO}_{2}$ levels after $\mathrm{HV}$ therapy also requires time to normalize; if $\mathrm{PaCO}_{2}$ rapidly increases, the perivascular $\mathrm{pH}$ (normalized by buffer systems) will decrease, causing local acidosis, vasodilatation, and an increase in CBV and ICP (also known as "rebound hyperemia") $(11,48)$.

\section{CLINICAL EVIDENCE OF HYPERVENTILATION THERAPY IN THE MANAGEMENT OF STBI}

For many years, HV was a key therapy in the control and prevention of posttraumatic ICH $(6-8,49-51)$. Oertel et al. reported that $\mathrm{HV}$ is a potent and more effective tool to lower elevated ICP levels when compared to increase mean arterial pressure (MABP) or decreased brain metabolism with propofol (52). Multiple studies indicate that the mechanism by which HV decreases ICP is vasoconstriction and $\mathrm{CBF}$ reduction $(3-5,10,11)$. As $\mathrm{CBF}$ decreases, the risk of ischemia is a latent danger $(8,10-12)$. This is a controversial matter that is subject to much debate.

Immediately following trauma, $\mathrm{CBF}$ decreases to about $40 \%$ and the $\mathrm{CMRO}_{2}$ possibly decreases as well (53-56). After at least $48 \mathrm{~h}$, this period is followed by two consecutive phases of "relative hyperemia" (in which CBF increases above metabolic demands) and vasospasm (57). The posttraumatic brain is extremely susceptible to ischemic damage (58-61). In almost half of all reported sTBI cases, the autoregulatory pressure mechanism is compromised; therefore, CBF becomes "pressure dependent" (58-61). Under different circumstances, the autoregulation pressure curve might shift to the right, which will increase the cerebral perfusion pressure (CPP) limit to help prevent ischemia (58-61). Because the brain needs to achieve a higher CPP during the acute phase of sTBI, it is highly recommended that hypotension should be avoided during this period. 
Much like CBF, arteriolar vasoreactivity to $\mathrm{CO}_{2}$ can vary according to region. $\mathrm{CO}_{2}$ reactivity is habitually maintained and exacerbated during the initial phase of trauma, especially in areas adjacent to contusions or subdural hematomas; a close proximity to these areas increases the likelihood of ischemia occurring in those regions (Figure 4$)(31,33,62)$. If $\mathrm{CO}_{2}$ reactivity becomes compromised, it is generally by a terminal event associated with poor results $(53,62-64)$. For these reasons, it is a key point at this stage in treatment to maintain $\mathrm{CBF}$ within normal limits to provide adequate $\mathrm{CPP}(\mathrm{CPP}=\mathrm{MABP}-\mathrm{ICP})$ and blood viscosity while avoiding resistance vessel constriction $(12,58-61)$.

\section{HYPERVENTILATION AND CEREBRAL ISCHEMIA}

Davis was the first to observe the slowing of electroencephalogram waves after $\mathrm{HV}$ and attributed this behavior to ischemia (65). Cold evaluated regional CBF (rCBF) using a Xenon (Xe-CT) technique before and after $\mathrm{HV}$ between the first day of admittance and 3 weeks post-sTBI (66). Under these conditions, mean ICP was reported to be $19 \mathrm{mmHg}$ and $\mathrm{PaCO}_{2}$ levels changed from 36 to $26 \mathrm{mmHg}$. The hyperventilated group demonstrated three times as many oligemic regions (defined by a $\mathrm{CBF}<20 \mathrm{ml} / 100$ $\mathrm{g} / \mathrm{min})$, and their areas of severe CBF reduction $(<15 \mathrm{ml} / 100 \mathrm{~g} / \mathrm{m})$ increased from 0.1 to $3 \%$. These observations were more evident in cerebral hemispheres with lower basal CBF. There was also a strong correlation between $\mathrm{HV}$, reductions in $\mathrm{rCBF}$, and poor patient outcome (66).

Multiple clinical studies examining sTBI have confirmed that HV causes significant reductions in CBF (67-69). But observing a reduction in $\mathrm{CBF}$ is not enough to accurately diagnose ischemia. To ascertain a valid diagnosis, tissue hypoxia must be associated with any observed decrease in CBF (37-40). Although they are not available in real time at the bedside, it is still important to perform metabolic studies, such as positron emission tomography (PET) (70).

A group from Cambridge conducted a series of studies in which they analyzed the effects of $\mathrm{HV}$ in patients with sTBI using PET (71-73). A common denominator among the patients was the absence of ICH (71-73). In the group's first study, 33 patients were tested within the first week of the trauma, and four were evaluated within the first $24 \mathrm{~h}$ of admission (71). The researchers decreased $\mathrm{PaCO}_{2}$ levels from a baseline of 36-29 mmHg. HV elevated CPP and decreased ICP and CBF, which increased the number and volume of areas that reached the hypoperfusion range. However, these changes were not associated with global ischemia since $\mathrm{SvjO}_{2}$ and the arterial-venous difference of $\mathrm{O}_{2}\left(\mathrm{AVDO}_{2}\right)$ remained within normal limits (71).

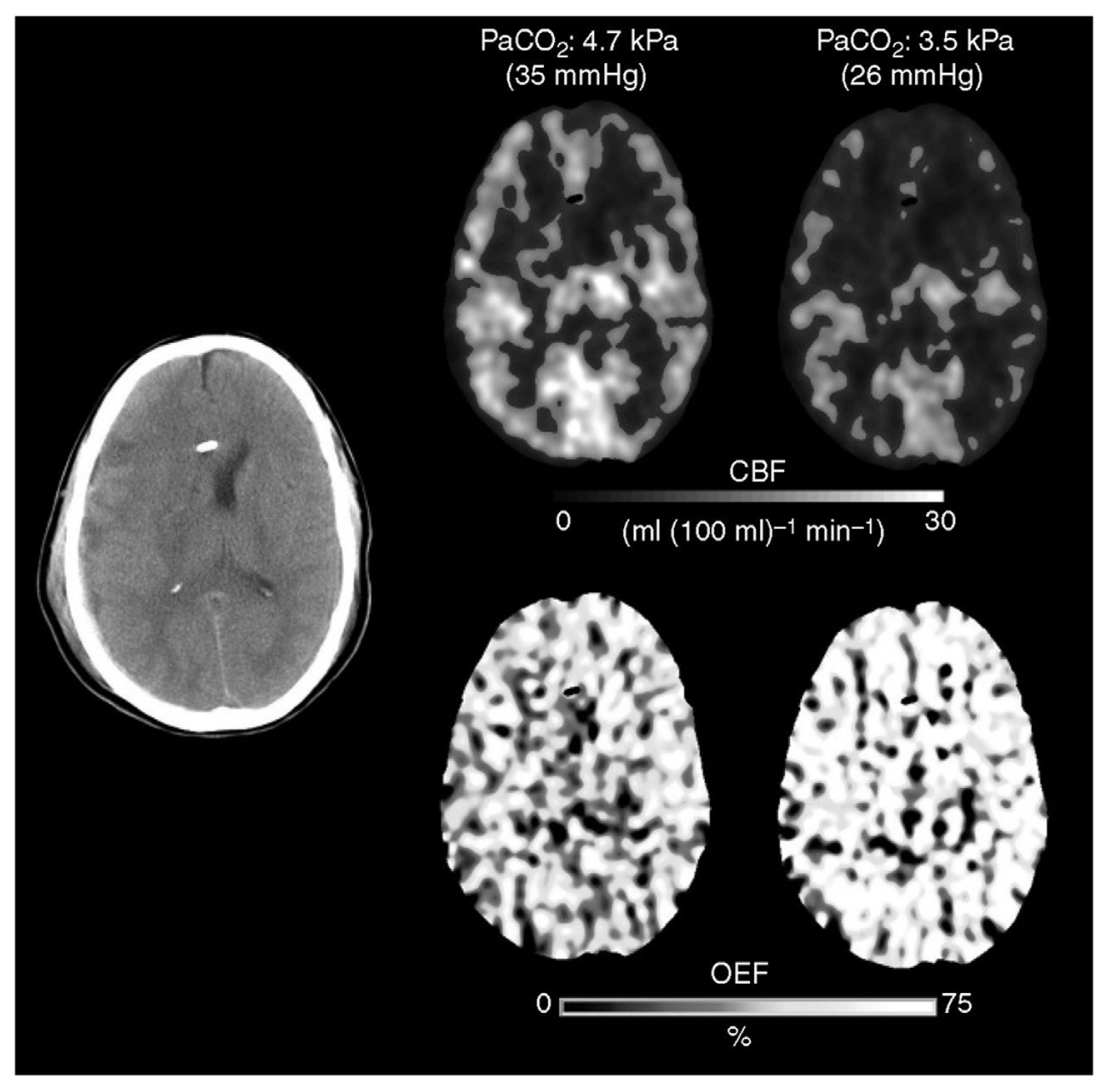

FIGURE 4 | The Xenon CT imaging that showed cerebral blood flow (CBF) decrease and $\mathrm{O}_{2}$ extraction fraction (OEF) increase after hyperventilation. 
In a subsequent study, 13 patients were analyzed during the same posttrauma period to test the hypothesis that diffusion alterations in microcirculation contribute to tissue hypoxia (72). The patients were monitored with $\mathrm{PET}, \mathrm{O}_{2}$ extraction fraction $(\mathrm{OEF})$, $\mathrm{ptiO}_{2}$, and $\mathrm{pvO}_{2}$ (72). Again, after inducing $\mathrm{HV}$ at a $29 \mathrm{mmHg}$ of $\mathrm{PaCO}_{2}, \mathrm{CBF}$ decreased. Areas in the range of hypoperfusion and hypoxia ( $\mathrm{ptiO}_{2}<10 \mathrm{mmHg}$ ) showed less reserve capacity to extract $\mathrm{O}_{2}$, which increased the risk of ischemic damage in these regions (72).

Using a modified PET technique $\left[\mathrm{O}_{2}(15)\right]$, Coles et al. evaluated $\mathrm{CBF}, \mathrm{CMRO}_{2}, \mathrm{CBV}$, and $\mathrm{OEF}$ in 30 sTBI patients within 10 days of trauma (73). Hypocapnia $\left(\mathrm{PaCO}_{2}=29 \mathrm{mmHg}\right)$ caused a decrease in $\mathrm{CBF}$, an increase in the volume of ischemic areas, and an increase in OEF. $\mathrm{CMRO}_{2}$ increased, but the response was heterogeneous. Twenty-eight percent of hyperventilated individuals showed a marked decrease in $\mathrm{CMRO}_{2} \cdot \mathrm{CMRO}_{2}$ correlated with neurophysiological monitoring findings (73).

In another series of sTBI patients with normal ICP values, the effects of $\mathrm{HV}$ and mannitol on $\mathrm{CBF}$ and metabolic variables were measured using a Doppler ultrasound device and blood samples were taken from a jugular catheter (74). The timing of the study was not specified. The authors reported that, when compared to the $20 \%(0.5 \mathrm{~g} / \mathrm{kg})$ mannitol group, the group hyperventilated at a target $\mathrm{PaCO}_{2}$ of $32 \mathrm{mmHg}$ had a lower CBF and $\mathrm{CMRO}_{2}$; glucose utilization (CMRGlu) and lactate production (CMRL) also increased in this group, which was interpreted by the authors as indicative of anaerobic hyperglycolysis (74).

Using Xe-CT, Stringer analyzed rCBF in 12 individuals with various etiologies, four of which were TBI patients (75). HV was induced heterogeneously with varying expired $\mathrm{CO}_{2}$ values $\left(\mathrm{ETCO}_{2}\right)$, three of them being lower than $20 \mathrm{mmHg}$. The study showed a decrease in $\mathrm{rCBF}$. No metabolic parameters were measured (75).

Using thermodiffusion and microdialysis, Marion analyzed $\mathrm{rCBF}$ and tissue hypoxia markers in the extracellular fluid of 20 individuals with sTBI before and after HV at a target of $24.6 \mathrm{mmHg}$ (76). Patients maintained normal ICP values. The authors analyzed "apparently healthy areas" adjacent to contusions or subdural hematomas during two-time intervals: 24-36 h and 3-4 days posttrauma (76). After HV, an increase in glutamate, lactate, and the lactate/pyruvate relationship (L/P) was observed to be $10 \%$ over basal values. CBF decreased by the same proportion. These changes were seen in both time intervals, but they were more frequently observed during the early stage post-TBI (76).

Using PET, Diringer tested the behavior of CBF, CBV, $\mathrm{CMRO}_{2}$, $\mathrm{OEF}$, and $\mathrm{CvO}_{2}$ after $\mathrm{HV}$ under a pre-specified target $\mathrm{PaCO}_{2}$ of $30 \mathrm{mmHg}$. Patients were analyzed an average of $11 \mathrm{~h}$ after sTBI. Of the nine individuals studied, only five had an ICP greater than $20 \mathrm{mmHg}$ (77). Reductions in $\mathrm{CBV}, \mathrm{CBF}$, and $\mathrm{CvO}_{2}$ were observed. There was no apparent ischemia or energy dysfunction since $\mathrm{CMRO}_{2}$ remained unchanged at the expense of an increase in OEF (77). Two years later, the same group used the same methodology to compare the effects of HV on patients with, and without ICH on posttrauma days 1 and 5 (78). The results they obtained and the conclusions they reached were no different from those reported in the previous study (78).

\section{HYPERVENTILATION AND CEREBRAL OXYGENATION}

$\mathrm{PaCO}_{2}$ affects the measurements taken by both global $\left(\mathrm{SvjO}_{2}\right)$ and regional $\left(\mathrm{ptiO}_{2}\right)$ oxygenation monitoring methods. $\mathrm{HV}$ reduces ICP levels, and clinical studies have demonstrated a simultaneous decrease in $\mathrm{SvjO}_{2}$ values (79-81). When analyzing the impact that $\mathrm{ETCO}_{2}$ levels have on $\mathrm{CBF}$ and $\mathrm{ptiO}_{2}$, a direct relationship has been observed between these variables, especially in the range of $\mathrm{ETCO}_{2}$ from 20 to $60 \mathrm{mmHg}(82)$. When $\mathrm{HV}$ is more intense and $\mathrm{ETCO}_{2}$ levels are lower, the likelihood of detecting tissue hypoxia using $\mathrm{ptiO}_{2}$ monitoring increases (83). Hypocapnia is one of the secondary insults that is likely to trigger tissue hypoxia (84). The effect HV has on tissue oxygenation becomes more dramatic as time goes on; it has the most impact around 5 days posttrauma $(85,86)$. This phenomenon is associated with poor results (86-88). Multiple clinical studies have established the deleterious effect $\mathrm{HV}$ has on $\mathrm{ptiO}_{2}$ levels. In sTBI, a lower $\mathrm{ptiO}_{2}$ has clearly become an independent predictor of mortality and poor patient outcome (86-89).

\section{HYPERVENTILATION AND STBI OUTCOME}

Only a few studies have established a correlation between patient outcome and HV. Two small studies concluded that mortality and poor functional outcomes were associated with HV when increasing the volume of areas with low $\mathrm{CBF}$ into the ischemic range (66) or when $\mathrm{ptiO}_{2}$ levels decreasing along with increasing $\mathrm{CO}_{2}$ reactivity 5 days after trauma (86).

Gordon reported a large retrospective series of patients treated with prolonged hyperventilation (90). 251 patients with sTBI were studied, 51 of whom were hyperventilated $\left(\mathrm{PaCO}_{2}\right.$ between 25 and $30 \mathrm{mmHg}$ ). The time period of HV varied between $6 \mathrm{~h}$ and 41 days (mean 10 days). The HV group had a lower mortality (9.8 vs. $32.8 \%)$; however, the number of survivors with severe neurological sequela notably increased. Patients who experienced a complete recovery did not differ between groups (90). The authors of the paper gave few details about their methodology; their reported clinical data was also incomplete.

There is only one prospective, controlled, and randomized study that evaluated the final outcome of sTBI patients who were treated with deep and prolonged (5 days) HV (91). Three groups were evaluated in this study: patients who received normoventilation $\left(\mathrm{PaCO}_{2} 35 \mathrm{mmHg}\right)$, patients who received $\mathrm{HV}$ at a $\mathrm{PaCO}_{2}$ of $25 \mathrm{mmHg}$, and patients who received HV and THAM (tromethamine). The THAM acted like a buffer, preventing $\mathrm{pH}$ changes within the extracellular cerebral fluid and CSF in order to extend the period during which HV was effective. Prior to randomization, patients were stratified into two groups according to the motor component of the Glasgow Coma Scale (GCS): $\leq 3$ or $>3$ points. Favorable results at 3 and 6 months of the event 
were significantly lower in the HV group, especially for patients who had a better clinical status at the time of admission (motor GCS 4-6). After a year had passed from the date of trauma, the differences between the groups were no longer significant. When evaluating $\mathrm{CBF}$ (Xe133) and $\mathrm{AVDO}_{2}$, there was no evidence of ischemia in any of the three groups (91).

The study's conclusions should be interpreted with caution. In the first place, the clinical and tomographic characteristics of the patients were not well balanced between the groups. The number of patients per group was also small, so there could have been statistical errors of type $\alpha$ (false positives). The control group was also hyperventilated with a mean $\mathrm{PaCO}_{2}$ at $31 \mathrm{mmHg}$. Third, it is apparent that $\mathrm{HV}$ was used prophylactically because only $14 \%$ of the individuals in the control and $\mathrm{HV}$ groups and $5 \%$ of the $\mathrm{HV}$ and THAM group had high ICP values. Finally, when analyzing the outcome at 12 months posttrauma, the best results correspond to $\mathrm{HV}+\mathrm{THAM}$ group.

\section{TARGET $\mathrm{PaCO}_{2}$ IN THE MANAGEMENT OF STBI}

The Cochrane collaboration concludes that there is an insufficient amount of evidence to clearly establish whether hyperventilation therapy in the management of sTBI is beneficial or detrimental (92). In emergent medical situations, Brain Trauma Foundation (BTF) guidelines recommend a brief period of hyperventilation (HV) (15-30 min to target $\mathrm{PaCO}_{2} 30-35 \mathrm{mmHg}$ ) to treat acute neurological deterioration reflecting increased ICP (12). However, in patients with TBI, the targeted $\mathrm{PaCO}_{2}$ of normoventilation is $35-40 \mathrm{mmHg}$ with a pulse oximetry of $95 \%$ or greater and/or $\mathrm{PaO}_{2}$ of $80 \mathrm{mmHg}$ or greater (12). If the patient is refractory to all other treatments, including hypertonic saline, sedation, and paralytics, a prolonged period of $\mathrm{HV}$ with brain oxygenation monitoring may be required to relieve ICH (12).

\section{RULES TO TAKE INTO ACCOUNT BEFORE HYPERVENTILATING A PATIENT WITH STBI}

Hyperventilation has a place in the management of ICP. For physicians to determine if there is a correct and sufficient indication for treatment with minimal possible risk for the patient, a systematic approach based on current scientific evidence must be undertaken. The authors recommend the following guidelines Figure 5:

- DO NOT hyperventilate prophylactically. HV will not prevent ICP increase, nor will it improve the final outcome.

- DO NOT hyperventilate in the absence of ICH.

- DO NOT hyperventilate for prolonged periods of time. At 4-6 h, buffer systems normalize the $\mathrm{pH}$ of the perivascular space, thereby negating the effects of hypocapnia on the cerebral vasculature.

- DO NOT hyperventilate within the first $24 \mathrm{~h}$ of sTBI, when the risk of ischemia is greatest.

- DO NOT hyperventilate without oxygenation monitoring.

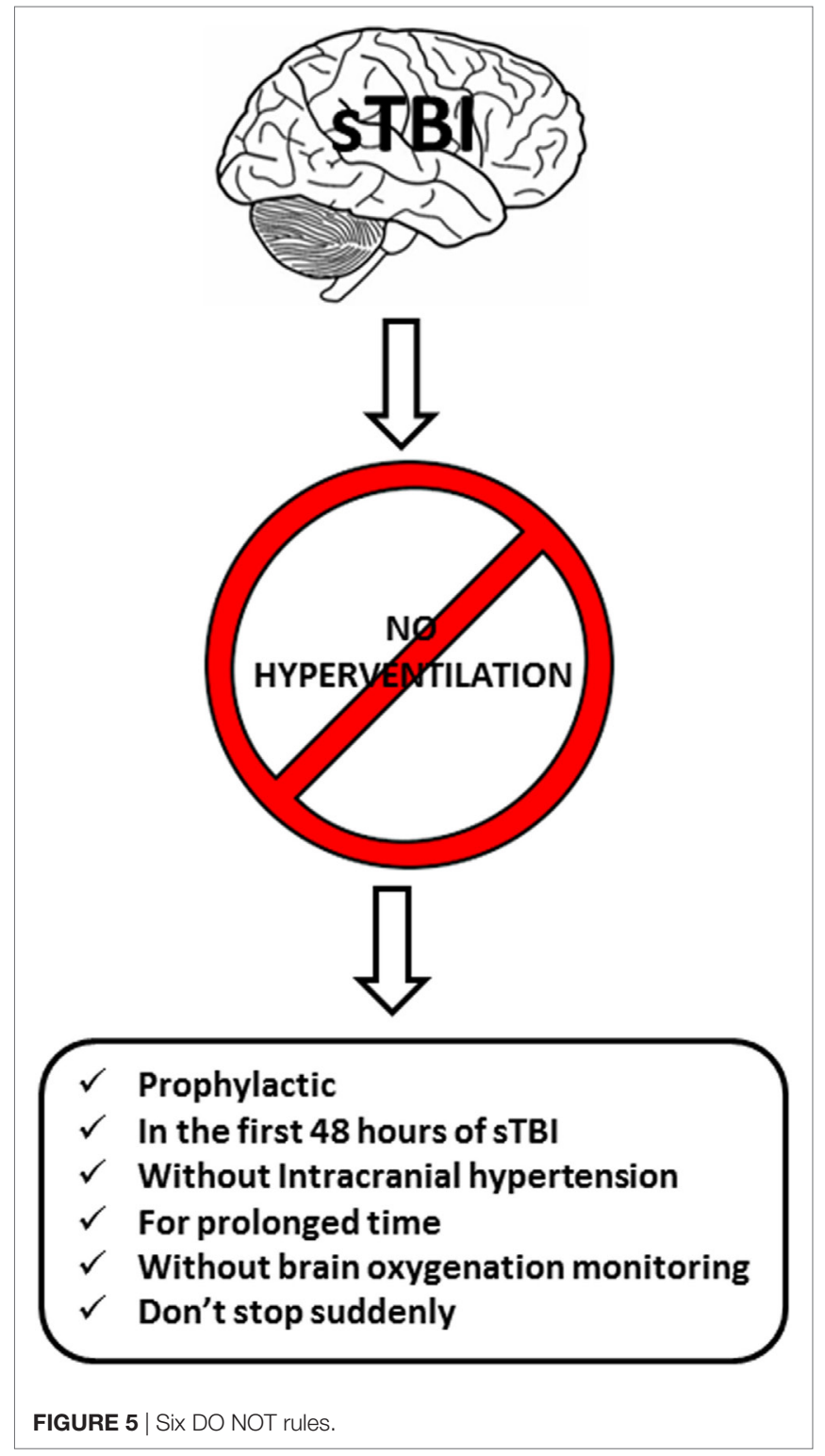

Consider using transcranial Doppler and measuring $\mathrm{CO}_{2}$ levels through the determination of expired $\mathrm{ETCO}_{2}$ levels or arterial gases. Because ischemic hypoxia is a latent and dangerous risk, monitor cerebral oxygenation globally $\left(\mathrm{SvjO}_{2}\right)$, locally $\left(\mathrm{ptiO}_{2}\right)$, or both despite the low level of evidence of this recommendation.

- DO NOT suddenly stop HV. Abrupt cessation will increase the risk of ICP elevation rebound.

\section{IDEAL CONDITIONS FOR HYPERVENTILATION}

The cerebral autoregulatory mechanism is compromised in more than half of reported sTBI cases, but HV can help ameliorate those circumstances $(93,94)$. However, the benefits derived from 
$\mathrm{HV}$ are transient and achievable only through moderate HV. A Doppler study examining 10 patients with sTBI demonstrated that $\mathrm{HV}$ at a $\mathrm{PaCO}_{2}$ of $28 \mathrm{mmHg}$ significantly improved cerebral autoregulation, but the benefit was lost when $\mathrm{HV}$ was reduced to a $\mathrm{PaCO}_{2}$ of $23 \mathrm{mmHg}$ (95). Another group composed of 30 sTBI individuals with normal ICP values evidenced improvement in autoregulation when $\mathrm{PaCO}_{2}$ levels were temporarily decreased from 38 to $33 \mathrm{mmHg}(96)$.
Hyperventilation is recommended as a temporary measure to reduce high levels of ICP in the following situations:

$\checkmark$ Herniation syndromes. These are syndromes involving the deterioration of neurological status (mydriasis, abnormal motor postures) secondary to expansive lesions (epidural, subdural hematomas, etc.) as a bridge to surgical resolution (12).

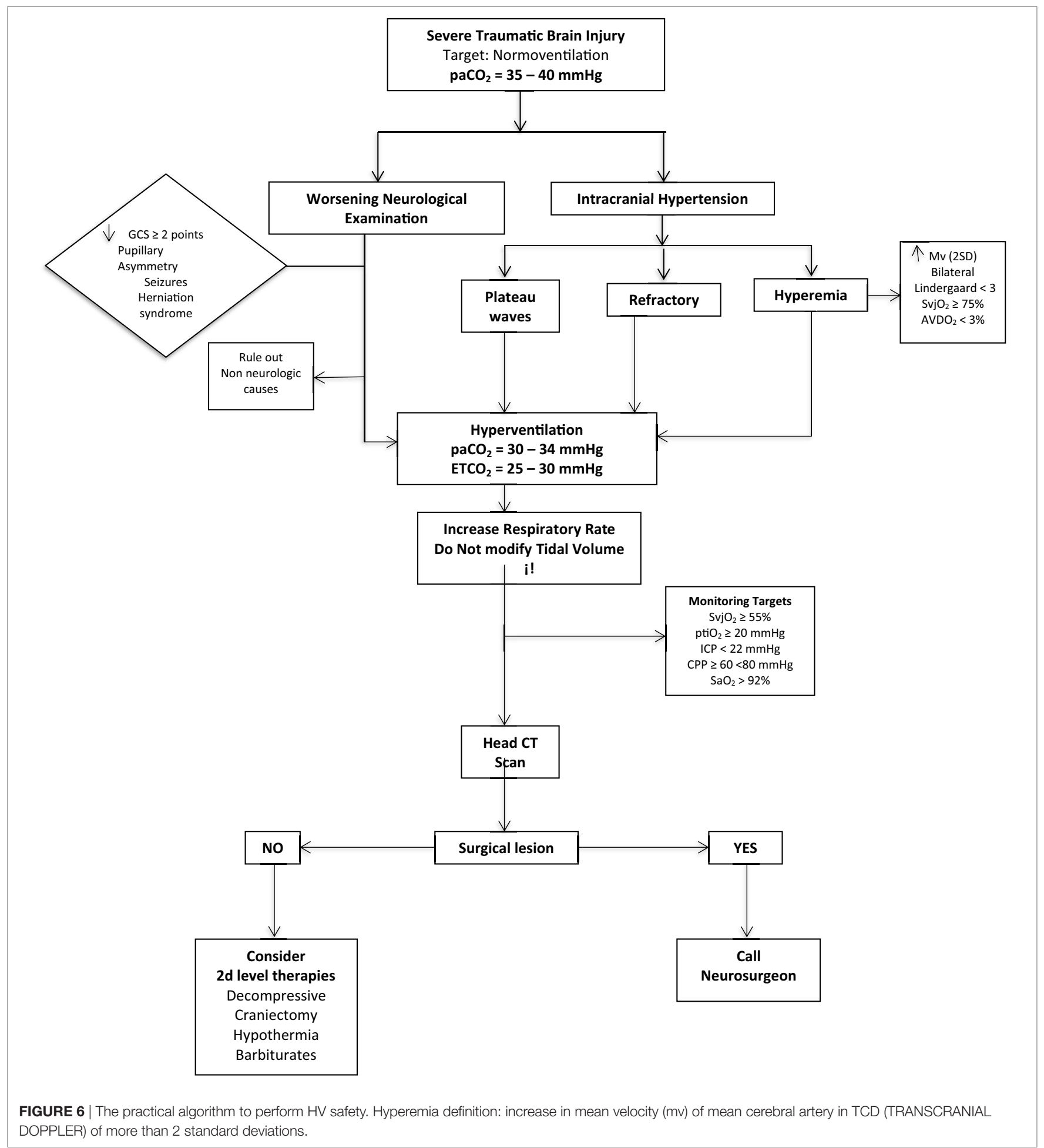


$\checkmark$ Life-threatening elevations of ICP. For example, type A plateau waves, while investigating triggers and expecting the effect of osmotherapy (12).

D Refractory ICH. HV is used in conjunction with second level measures, such as decompressive craniectomy, hypothermia, or high doses of barbiturates (12).

D ICH secondary to "hyperemia."

In approximately $20 \%$ of sTBI cases, ICP elevation correlates with high $\mathrm{CBF}$ in excess to metabolic demands, mainly in young individuals $(53,97,98)$. In these situations, based on the principle of coupling between $\mathrm{CBF}$ and $\mathrm{CMRO}_{2}$, the concept of "optimiz-

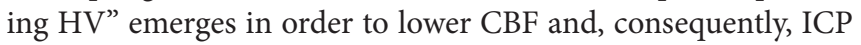
without modifying $\mathrm{CMRO}_{2}$ (99-102). By implementing this approach alongside cerebral oxygenation monitoring through $\mathrm{SvjO}_{2}$ and associated variables, Cruz et al. calibrate $\mathrm{HV}$ to a target $\mathrm{PaCO}_{2}$ that varied from 18 to $30 \mathrm{mmHg}$. As a result, ICP decreased without modification in $\mathrm{CMRO}_{2}$ while $\mathrm{OEF}$ increased (98-102). In another series of sTBI patients, it was reported that $\mathrm{HV}$ contributed to the stabilization and improvement of brain glucose uptake (101).

Hyperventilation optimization has its limitations. It is based on global monitoring that does not take into account the regional differences in $\mathrm{CBF}$, metabolism, or $\mathrm{CO}_{2}$ reactivity. ICP compartmentalization and lesion type (focal or diffuse) are similarly disregarded in this manner. There does not exist a consistent definition of "hyperemia," especially about the monitoring methods available at the bedside. There are also multiple limitations to the method of oxygenation monitoring itself, which can make it difficult to interpret the data obtained from said monitoring.

\section{REFERENCES}

1. Diringer M. Hyperventilation in head injury: what have we learned in 43 years? Crit Care Med (2002) 30:2142-3. doi:10.1097/00003246200209000-00032

2. Lundberg N. Continuous recording and control of ventricular fluid pressure in neurosurgical practice. Acta Psychiatr Scand Suppl (1960) 36:1-193.

3. Raichle ME, Plum F. Hyperventilation and cerebral blood flow. Stroke (1972) 3:566-75. doi:10.1161/01.STR.3.5.566

4. Heffner JE, Sahn SA. Controlled hyperventilation in patients with intracranial hypertension. Application and management. Arch Intern Med (1983) 143:765-9. doi:10.1001/archinte.1983.00350040155022

5. Brian JE. Carbon dioxide and the cerebral circulation. Anesthesiology (1998) 88:365-86. doi:10.1097/00000542-199805000-00029

6. Ghajar J, Hariri R, Narayan R. Survey of critical care management of comatose, head injured patients in the United States. Crit Care Med (1995) 23:560-7. doi:10.1097/00003246-199503000-00023

7. Matta B, Menon D. Severe head injury in the United Kingdom and Ireland: a survey of practice and implications for management. Crit Care Med (1996) 24:1743-8. doi:10.1097/00003246-199610000-00023

8. Brain Trauma Foundation, American Association of Neurological Surgeons, Congress of Neurological Surgeons. Guidelines for the management of severe traumatic brain injury. J Neurotrauma (2007) 24(Suppl 1):S1-106. doi:10.1089/neu.2007.9999

9. Neumann JO, Chambers IR, Citerio G, Enblad P, Gregson BA, Howells T, et al. The use of hyperventilation therapy after traumatic brain injury in Europe: an analysis of the brain IT database. Intensive Care Med (2008) 34:1676-82. doi:10.1007/s00134-008-1123-7

10. Stochetti N, Maas AI, Chieragato A, van der Plas AA. Hyperventilation in head injury. Chest (2005) 127:1812-27. doi:10.1378/chest.127.5.1812

\section{HYPERVENTILATION TECHNIQUES}

In Figure 6, we outline a practical algorithm summarizing the concepts one should take into consideration when hyperventilating a patient.

\section{CONCLUSION}

Patients with an elevated ICP require emergent intervention to prevent deleterious consequences. Under certain conditions, when cerebrovascular $\mathrm{CO}_{2}$ reactivity is intact, $\mathrm{HV}$ can be used temporarily to induce hypocapnia to elicit arteriolar vasoconstriction with the aim of decreasing CBF and, ultimately, ICP. The cerebral effects of hypocapnia are transient. Because profound and prolonged HV carries the risk of ischemia, it is important that the therapy be closely monitored to prevent any adverse cerebral effects.

Hyperventilation has serious systemic consequences. It should not be implemented during the first $24 \mathrm{~h}$ of trauma when CBF is markedly reduced. Prophylactic HV or HV without an indication of elevated ICP will not yield any benefits. Current recommendations suggest that a brief period of $\mathrm{HV}$ (15-30 min) with a $\mathrm{PaCO}_{2}$ target of $30-35 \mathrm{mmHg}$ and $\mathrm{CPP}$ target of $60-70 \mathrm{mmHg}$ coupled with close oxygenation neuromonitoring is an effective method of controlling $\mathrm{ICH}$ during the acute-phase of sTBI.

\section{AUTHOR CONTRIBUTIONS}

All authors contribute to the preparation of the manuscript in the same manner.

11. Curley G, Kavanagh BP, Laffey JG. Hypocapnia and the injured brain: more harm than benefit. Crit Care Med (2010) 38:1348-59. doi:10.1097/ CCM.0b013e3181d8cf2b

12. Carney N, Totten AM, O’Reilly C, Ullman JS, Hawryluk GW, Bell MJ, et al. Guidelines for the management of severe traumatic brain injury, fourth edition. Neurosurgery (2017) 80:6-15. doi:10.1227/ NEU.0000000000001432

13. West JB, Luks AM. Respiratory Physiology: The Essentials. 10th ed. Philadelphia, USA: Wolters Kluwer (2016).

14. Laffey JG, Kavanagh BP. Hypocapnia. N Engl J Med (2002) 347:43-53. doi:10.1056/NEJMra012457

15. Stoelting RK, Hillier SC. Acid-base balance. In: Stoelting RK, Hillier SC, editors. Pharmacology and Physiology in Anesthetic Practice. Philadelphia: Lippincott Williams and Wilkins (2006). p. 794-802.

16. Vazquez Garcia JC, Perez Padilla R. Valores gasométricos estimados para las principales poblaciones y sitios a mayor altitud. Rev Inst Nal Enf Resp Mex (2000) 13:6-13.

17. Restrepo J, Reyes P, Vasquez P, Ardila M, Diaz Granados B. Gasometria arterial y alveolar en adultos sanos a nivel de Bogota. Acta Med Colomb (1982) 7:461-6.

18. Llanos M, Villanagua B, Garelli Z, Freund P, Finol D, Gonzalez A, et al. Investigacion en Medicina Critica. Interpretacion de los gases sanguíneos arteriales a nivel de Quito, Ecuador. Biomed J (2016) 1:1-9.

19. Pereira Victorio CJ, Huamanquispe Quintana J, Castelo Tamayo LE. Gasometria arterial en adultos clínicamente sanos a 3350 metros de altutud. Rev Peru Med Exp Salud Publica (2014) 31:473-9.

20. Hinojosa Campero WE. Gasometria arterial y adaptación a la altura. Rev Med Cient (2011) 2:39-45.

21. Godoy DA, Canitrot Ugarte M. Physiological basis for the correct interpretation of different situations in acute cerebral injury. In: Godoy DA, editor 
Intensive Care in Neurology and Neurosurgery (Vol. 1, Chap. 3), Torino, Italy: Seed (2013). p. 53-68.

22. Aaslid R, Lindegaard KF, Sorteberg W, Nornes H. Cerebral autoregulation dynamics in humans. Stroke (1989) 20:45-52. doi:10.1161/01. STR.20.1.45

23. Czosnyka M, Brady K, Reinhard M, Smielewski P, Steiner LA. Monitoring of cerebrovascular autoregulation: facts, myths, and missing links. Neurocrit Care (2009) 10:373-86. doi:10.1007/s12028-008-9175-7

24. Cold GE. Cerebral blood flow in acute head injury. The regulation of cerebral blood flow and metabolism during the acute phase of head injury, and its significance for therapy. Acta Neurochir Suppl (Wien) (1990) 49:1-64.

25. Harper AM, Glass HI. Effect of alterations in the arterial carbondioxide tension on the blood flow through the cerebral cortex at normal and low arterial blood pressures. J Neurol Neurosurg Psychiatry (1965) 28:449-52. doi:10.1136/jnnp.28.5.449

26. Kontos HA, Raper AJ, Patterson JL. Analysis of vasoactivity of local pH, $\mathrm{PCO}_{2}$ and bicarbonate on pial vessels. Stroke (1977) 8:358-60. doi:10.1161/01. STR.8.3.358

27. Ingvar DH, Cronqvist S, Ekberg R, Risberg J, Hoedt-Rasmussen K. Normal values of regional cerebral blood flow in man, including flow and weight estimated of gray and white matter. Acta Neurol Scand Suppl (1965) 14:72.

28. Ito H, Yokoyama I, Lida H, Kinoshita T, Hatazawa J, Shimosegawa E, et al. Regional differences in cerebral vascular response to $\mathrm{PaCO}_{2}$ changes in humans measured by positron emission tomography. J Cereb Blood Flow Metab (2000) 20:1264-70. doi:10.1097/00004647-200008000-00011

29. Bouma GJ, Muizelaar JP. Cerebral blood flow, cerebral blood volume, and cerebrovascular reactivity after severe head injury. J Neurotrauma (1992) 9(Suppl 1):S333-48.

30. Bouma GJ, Muizelaar JP, Stringer WA, Choi SC, Fatouros P, Young HF. Ultraearly evaluation of regional cerebral blood flow in severely head-injured patients using xenon-enhanced computerized tomography. J Neurosurg (1992) 77:360-8. doi:10.3171/jns.1992.77.3.0360

31. McLaughlin MR, Marion DW. Cerebral blood flow and vasoresponsivity within and around cerebral contusions. JNeurosurg (1996) 85:871-6. doi:10.3171/jns.1996.85.5.0871

32. Marion DW, Firlik A, McLaughlin MR. Hyperventilation therapy for severe traumatic brain injury. New Horiz (1995) 3:439-47.

33. Ito H, Ibaraki M, Kanno I, Fukuda H, Miura S. Changes in the arterial fraction of human cerebral blood volume during hypercapnia and hypocapnia measured by positron emission tomography. JCereb Blood Flow Metab (2005) 25:852-7. doi:10.1038/sj.jcbfm.9600076

34. Ito H, Kanno I, Iida H, Hatazawa J, Shimosegawa E, Tamura H, et al. Arterial fraction of cerebral blood volume in humans measured by positron emission tomography. Ann Nucl Med (2001) 15:111-6. doi:10.1007/BF02988600

35. Fortune JB, Feustel PJ, deLuna C, Graca L, Hasselbarth J, Kupinski AM. Cerebral blood flow and blood volume in response to $\mathrm{O}_{2}$ and $\mathrm{CO}_{2}$ changes in normal humans. J Trauma (1995) 39:463-71. doi:10.1097/ 00005373-199509000-00012

36. Cardoso ER, Rowan JO, Galbraith S. Analysis of the cerebrospinal fluid pulse wave in intracranial pressure. J Neurosurg (1983) 59:817-21. doi:10.3171/ jns.1983.59.5.0817

37. Siggaard-Andersen O, Ulrich A, Gothgen IH. Classes of tissue hypoxia. Acta Anaesthesiol Scand Suppl (1995) 107:137-42. doi:10.1111/j.1399-6576.1995. tb04348.x

38. Zauner A, Daugherty WP, Bullock MR, Warner DS. Brain oxygenation and energy metabolism: part I-biological function and pathophysiology. Neurosurgery (2002) 51:289-301. doi:10.1097/00006123-200208000-00003

39. Marín-Caballos AJ, Murillo-Cabezas F, Domínguez-Roldan JM, LealNoval SR, Rincón-Ferrari MD, Muñoz-Sánchez MÁ. Monitorización de la presión tisular de oxígeno $\left(\mathrm{PtiO}_{2}\right)$ en la hipoxia cerebral: aproximación diagnóstica y terapéutica. Med Intensiva (2008) 32:81-90. doi:10.1016/ S0210-5691(08)70912-4

40. Le Roux P, Menon DK, Citerio G, Vespa P, Bader MK, Brophy GM, et al. Consensus summary statement of the International Multidisciplinary Consensus Conference on Multimodality Monitoring in Neurocritical Care: a statement for healthcare professionals from the Neurocritical Care Society and the European Society of Intensive Care Medicine. Neurocrit Care (2014) 21(Suppl 2):S1-26. doi:10.1007/s12028-014-0041-5
41. Marhong J, Fan E. Carbon dioxide in the critically ill: too much or too little of a good thing. Respir Care (2014) 59:1597-605. doi:10.4187/respcare.03405

42. Go SL, Singh JM. Pro/con debate: should $\mathrm{PaCO}_{2}$ be tightly controlled in all patients with acute brain injuries? Crit Care (2013) 17:202. doi:10.1186/ cc11389

43. Mazzeo AT, Fanelli V, Mascia L. Brain-lung crosstalk in critical care: how protective mechanical ventilation can affect the brain homeostasis. Minerva Anestesiol (2013) 79:299-309.

44. Graham EM, Apostolou M, Mishra OP, Delivoria-Papadopoulos M. Modification of the $N$-methyl-D-aspartate (NMDA) receptor in the brain of newborn piglets following hyperventilation induced ischemia. Neurosci Lett (1996) 218:29-32. doi:10.1016/0304-3940(96)13114-1

45. Pastuszko P, Wilson DF. Activation of tyrosine hydroxylase in striatum of newborn piglets in response to hypocapnic ischemia and recovery. $A d v$ Exp Med Biol (1997) 411:65-73. doi:10.1007/978-1-4615-5865-1_8

46. Mykita S, Golly F, Dreyfus H, Freysz L, Massarelli R. Effect of CDP-choline on hypocapnic neurons in culture. J Neurochem (1986) 47:223-31. doi:10.1111/ j.1471-4159.1986.tb02853.x

47. Raichle ME, Posner JB, Plum F. Cerebral blood flow during and after hyperventilation. Arch Neurol (1970) 23:394-403. doi:10.1001/ archneur.1970.00480290014002

48. Muizelaar JP, van der Poel HG, Li ZC, Kontos HA, Levasseur JE. Pial arteriolar vessel diameter and $\mathrm{CO}_{2}$ reactivity during prolonged hyperventilation in the rabbit. J Neurosurg (1988) 69:923-7. doi:10.3171/jns.1988.69.6.0923

49. Bruce DA, Alavi A, Bilaniuk L, Dolinskas C, Obrist W, Uzzell B. Diffuse cerebral swelling following head injuries in children: the síndrome of malignant brain edema. J Neurosurg (1981) 54:170-8. doi:10.3171/jns.1981.54.2.0170

50. Becker DP, Gardner S. Intensive management of head injury. In: Wilkins RH, Rengachary SS, editors. Neurosurgery (Vol. 2), New York: McGraw-Hill (1985). p. 1593-9.

51. Marshall LF, Marshall S. Medical management of intracranial pressure. 2nd ed. In: Cooper PR, editor. Head Injury. Baltimore: Williams \& Wilkins (1987). p. $177-96$.

52. Oertel M, Kelly DF, Lee JH, Mc Arthur DL, Glenn TC, Vespa P, et al. Efficacy of hyperventilation, blood pressure elevation, and metabolic suppression therapy in controlling intracranial pressure after head injury. J Neurosurg (2002) 97:1045-53. doi:10.3171/jns.2002.97.5.1045

53. Obrist WD, Langfitt TW, Jaggi JL, Cruz J, Gennarelli TA. Cerebral blood flow and metabolism in comatose patients with acute head injury. J Neurosurg (1984) 61:241-53. doi:10.3171/jns.1984.61.2.0241

54. Bouma GJ, Muizelaar JP, Choi SC, Newlon PG, Young HF. Cerebral circulation and metabolism after severe traumatic brain injury: the elusive role of ischemia. J Neurosurg (1991) 75:685-93. doi:10.3171/jns.1991. 75.5.0685

55. Jaggi JL, Obrist WD, Gennarelli TA, Langfitt TW. Relationship of early cerebral blood flow and metabolism to outcome in acute head injury. J Neurosurg (1990) 72:176-82. doi:10.3171/jns.1990.72.2.0176

56. Marion DW, Darby J, Yonas H. Acute regional cerebral blood flow changes caused by severe head injuries. J Neurosurg (1991) 74:407-14. doi:10.3171/ jns.1991.74.3.0407

57. Martin NA, Patwardhan RV, Alexander MJ, Africk CZ, Lee JH, Shalmon E, et al. Characterization of cerebral hemodynamic phases following severe head trauma: hypoperfusion, hyperemia, and vasospasm. J Neurosurg (1997) 87:9-19. doi:10.3171/jns.1997.87.1.0009

58. Chesnut RM. Care of central nervous system injuries. Surg Clin North Am (2007) 87:119-56. doi:10.1016/j.suc.2006.09.018

59. Stochetti N, Maas AI. Traumatic intracranial hypertension. N Engl J Med (2014) 370:2121-30. doi:10.1056/NEJMra1208708

60. Perez-Barcena J, Lompart-Pou JA, O’Phelan KH. Intracranial pressure monitoring and management of intracranial hypertension. Crit Care Clin (2014) 30:735-50. doi:10.1016/j.ccc.2014.06.005

61. Kirkman MA, Smith M. Intracranial pressure monitoring, cerebral perfusion pressure estimation, and ICP/CPP-guided therapy: a standard of care or optional extra after brain injury? Br J Anaesth (2014) 112(1):35-46. doi:10.1093/bja/aet418

62. Paolini A, Rodriguez G, Betetto M, Simini G. Cerebral hemodynamic response to $\mathrm{CO}_{2}$ after severe head injury: clinical and prognostic implications. J Trauma (1998) 44:495-500. doi:10.1097/ 00005373-199803000-00012 
63. Marion DW, Bouma GJ. The use of stable xenon-enhanced computed tomography studies of cerebral blood flow to define changes in cerebral carbon dioxide vasoresponsivity caused by a severe head injury. Neurosurgery (1991) 29:869-73. doi:10.1097/00006123-199112000-00011

64. Tenjin H, Yamaki T, Nakagawa Y, Kuboyama T, Ebisu T, Kobori N, et al. Impairment of $\mathrm{CO}_{2}$ reactivity in severe head injury patients: an investigation using thermal diffusion method. Acta Neurochir (Wien) (1990) 104:121-5. doi:10.1007/BF01842829

65. Davis H, Wallace WM. Factors affecting changes produced in electroencephalogram by standardized hyperventilation. Arch Neurol Psychiat (1942) 47:606-25. doi:10.1001/archneurpsyc.1942.02290040096005

66. Cold GE. Does acute hyperventilation provoke cerebral oligaemia in comatose patients after acute head injury? Acta Neurochir (Wien) (1989) 96:100-6. doi:10.1007/BF01456166

67. Skippen P, Seear M, Poskitt K, Kestle J, Cochrane D, Annich G, et al. Effect of hyperventilation on regional cerebral blood flow in head-injured children. Crit Care Med (1997) 25:1402-9. doi:10.1097/ 00003246-199708000-00031

68. Dahl B, Bergholt B, Cold GE, Astrup J, Mosdal B, Jensen K, et al. CO(2) and indomethacin vasoreactivity in patients with head injury. Acta Neurochir (Wien) (1996) 138:265-73. doi:10.1007/BF01411736

69. Sioutos PJ, Orozco JA, Carter LP, Weinand ME, Hamilton AJ, Williams FC. Continuous regional cerebral cortical blood flow monitoring in headinjured patients. Neurosurgery (1995) 36:943-9. doi:10.1227/00006123199505000-00009

70. Coles JP, Fryer TD, Smielewski P, Rice K, Clark JC, Pickard JD, et al. Defining ischemic burden after traumatic brain injury using 150 PET imaging of cerebral physiology. J Cereb Blood Flow Metab (2004) 24:191-201. doi:10.1097/01. WCB.0000100045.07481.DE

71. Coles JP, Minhas PS, Fryer TD, Smielewski P, Aigbirihio F, Donovan T, et al. Effect of hyperventilation on cerebral blood flow in traumatic head injury: clinical relevance and monitoring correlates. Crit Care Med (2002) 30:1950-9. doi:10.1097/00003246-200209000-00002

72. Menon DK, Coles JP, Gupta AK, Fryer TD, Smielewski P, Chatfield DA, et al. Diffusion limited oxygen delivery following head injury. Crit Care Med (2004) 32:1384-90. doi:10.1097/01.CCM.0000127777.16609.08

73. Coles JP, Fryer TD, Coleman MR, Smielewski P, Gupta AK, Minhas PS, et al. Hyperventilation following head injury: effect on ischemic burden and cerebral oxidative metabolism. Crit Care Med (2007) 35:568-78. doi:10.1097/01. CCM.0000254066.37187.88

74. Soustiel JF, Mahamid E, Chistyakov A, Shik V, Benenson R, Zaaroor M. Comparison of moderate hyperventilation and mannitol for control of intracranial pressure control in patients with severe traumatic brain injury - a study of cerebral blood flow and metabolism. Acta Neurochir (Wien) (2006) 148:845-51. doi:10.1007/s00701-006-0792-7

75. Stringer WA, Hasso AN, Thompson JR, Hinshaw DB, Jordan KG. Hyperventilation induced cerebral ischemia in patients with acute brain lesions: demonstration by xenon CT. AJNR Am J Neuroradiol (1993) 14:475-84.

76. Marion DW, Puccio A, Wisniewski SR, Kochanek P, Dixon CE, Bullian L. Effect of hyperventilation on extracellular concentrations of glutamate, lactate, pyruvate and local cerebral blood flow in patients with severe traumatic brain injury. Crit Care Med (2002) 30:2619-25. doi:10.1097/00003246-200212000-00001

77. Diringer MN, Yundt K, Videen TO, Adams RE, Zazulia AR, Deibert E, et al. No reduction in cerebral metabolism as a result of early moderate hyperventilation following severe traumatic brain injury. J Neurosurg (2000) 92:7-13. doi:10.3171/jns.2000.92.1.0007

78. Diringer MN, Videen TO, Yundt K, Zazulia AR, Aiyagari V, Dacey RG, et al. Regional cerebrovascular and metabolic effects of hyperventilation after severe traumatic brain injury. J Neurosurg (2002) 96:103-8. doi:10.3171/ jns.2002.96.1.0103

79. Unterberg AW, Kiening KL, Härtl R, Bardt T, Sarrafzadeh AS, Lanksch WR. Multimodal monitoring in patients with head injury: evaluation of the effects of treatment on cerebral oxygenation. J Trauma (1997) 42:S32-7. doi:10.1097/00005373-199705001-00006

80. Thiagarajan A, Goverdhan PD, Chari P, Somasunderam K. The effect of hyperventilation and hyperoxia on cerebral venous oxygen saturation in patients with traumatic brain injury. Anesth Analg (1998) 87:850-3. doi:10.1213/00000539-199810000-00019

81. Rangel-Castilla L, Lara LR, Gopinath S, Swank PR, Valadka A, Robertson C. Cerebral hemodynamic effects of acute hyperoxia and hyperventilation after severe traumatic brain injury. J Neurotrauma (2010) 27:1853-63. doi:10.1089/neu.2010.1339

82. Hemphill JC III, Knudson MM, Derugin N, Morabito D, Manley GT. Carbon dioxide reactivity and pressure autoregulation of brain tissue oxygen. Neurosurgery (2001) 48:377-83. doi:10.1227/00006123-200102000-00028

83. Carrera E, Schmidt JM, Fernandez L, Kurtz P, Merkow M, Stuart M, et al. Spontaneous hyperventilation and brain tissue hypoxia in patients with severe brain injury. J Neurol Neurosurg Psychiatry (2010) 81:793-7. doi:10.1136/jnnp.2009.174425

84. Sarrafzadeh AS, Kiening KL, Callsen TA, Unterberg AW. Metabolic changes during impending and manifest cerebral hypoxia in traumatic brain injury. Br J Neurosurg (2003) 17:340-6. doi:10.1080/02688690310 001601234

85. Gopinath SP, Valadka AB, Uzura M, Robertson CS. Comparison of jugular venous oxygen saturation and brain tissue $\mathrm{Po}_{2}$ as monitors of cerebral ischemia after head injury. Crit Care Med (1999) 27:2337-45. doi:10.1097/00003246-199911000-00003

86. Carmona Suazo JA, Maas AI, van den Brink WA, van Santbrink $H$, Steyerberg EW, Avezaat CJ. $\mathrm{CO}_{2}$ reactivity and brain oxygen pressure monitoring in severe head injury. Crit Care Med (2000) 28:3268-74. doi:10.1097/00003246-200009000-00024

87. Fandino J, Stocker R, Prokop S, Imhof HG. Correlation between jugular bulb oxygen saturation and partial pressure of brain tissue oxygen during $\mathrm{CO}_{2}$ and $\mathrm{O}_{2}$ reactivity tests in severely head-injured patients. Acta Neurochir (Wien) (1999) 141:825-34. doi:10.1007/s007010050383

88. Dings J, Meixensberger J, Amschler J, Hamelbeck B, Roosen K. Brain tissue $\mathrm{PO}_{2}$ in relation to cerebral perfusion pressure, TCD findings and TCD-CO reactivity after severe head injury. Acta Neurochir (Wien) (1996) 138:425-34. doi:10.1007/BF01420305

89. van den Brink WA, van Santbrink H, Steyerberg EW, Avezaat CJ, Suazo JA, Hogesteeger C, et al. Brain oxygen tension in severe head injury. Neurosurgery (2000) 46:868-76. doi:10.1227/00006123-200004000-00018

90. Gordon E. Controlled respiration in the management of patients with traumatic brain injuries. Acta Anaesth Scand (1971) 15:193-208. doi:10.1111/ j.1399-6576.1971.tb05461.x

91. Muizelaar JP, Marmarou A, Ward JD, Kontos HA, Choi SC, Becker DP, et al. Adverse effects of prolonged hyperventilation in patients with severe head injury: a randomized clinical trial. J Neurosurg (1991) 75:731-9. doi:10.3171/ jns.1991.75.5.0731

92. Roberts I, Schierhout G. Hyperventilation therapy for acute traumatic brain injury. Cochrane Database Syst Rev (1997) 4(4):CD000566. doi:10.1002/14651858.CD000566 Updated 2009

93. Bouma GJ, Muizelaar JP, Bandoh K, Marmarou A. Blood pressure and intracranial pressure volume dynamics in severe head injury: relationship with cerebral blood flow. J Neurosurg (1992) 77:15-9. doi:10.3171/ jns.1992.77.1.0015

94. Hlatky R, Valadka AB, Robertson CS. Intracranial pressure response to induced hypertension: role of dynamic pressure autoregulation. Neurosurgery (2005) 57:917-23. doi:10.1227/01.NEU.0000180025.43747.fc

95. Newell DW, Weber JP, Watson R, Aaslid R, Winn HR. Effect of transient moderate hyperventilation on dynamic cerebral autoregulation after severe head injury. Neurosurgery (1996) 39:35-43. doi:10.1227/00006123-19960900000056

96. Steiner LA, Balestreri M, Johnston AJ, Coles JP, Chatfield DA, Pickard JD, et al. Effects of moderate hyperventilation on cerebrovascular pressurereactivity after head injury. Acta Neurochir Suppl (2005) 95:17-20. doi:10.1007/3-211-32318-X_4

97. Kelly DF, Kordestani RK, Martin NA, Nguyen T, Hovda DA, Bergsneider M, et al. Hyperemia following traumatic brain injury: relationship to intracranial hypertension and outcome. JNeurosurg (1996) 85:762-71. doi:10.3171/ jns.1996.85.5.0762

98. Muizelaar JP, Marmarou A, DeSalles AA, Ward JD, Zimmerman RS, Li Z, et al. Cerebral blood flow and metabolism in severely head-injured children. 
Part 1: relationship with GCS score, outcome, ICP, and PVI. J Neurosurg (1989) 71:63-71. doi:10.3171/jns.1989.71.1.0063

99. Cruz J. Combined continuous monitoring of systemic and cerebral oxygenation in acute brain injury: preliminary observations. Crit Care Med (1993) 21:1225-32. doi:10.1097/00003246-199308000-00025

100. Cruz J, Jaggi JL, Hoffstad OJ. Cerebral blood flow, vascular resistance, and oxygen metabolism in acute brain trauma: redefining the role of cerebral perfusion pressure? Crit Care Med (1995) 23:1412-7. doi:10.1097/00003246-199508000-00016

101. Cruz J. An additional therapeutic effect of adequate hyperventilation in severe acute brain trauma: normalization of cerebral glucose uptake. J Neurosurg (1995) 82:379-85. doi:10.3171/jns.1995.82.3.0379

102. Cruz J. The first decade of continuous monitoring of jugular bulb oxyhemoglobinsaturation: management strategies and clinical outcome. Crit Care Med (1998) 26:344-51. doi:10.1097/00003246-199802000-00039
Conflict of Interest Statement: The authors declare that the research was conducted in the absence of any commercial or financial relationships that could be construed as a potential conflict of interest.

The reviewer, BA, and handling editor declared their shared affiliation, and the handling editor states that the process nevertheless met the standards of a fair and objective review.

Copyright (๔ 2017 Godoy, Seifi, Garza, Lubillo-Montenegro and Murillo-Cabezas. This is an open-access article distributed under the terms of the Creative Commons Attribution License (CC BY). The use, distribution or reproduction in other forums is permitted, provided the original author(s) or licensor are credited and that the original publication in this journal is cited, in accordance with accepted academic practice. No use, distribution or reproduction is permitted which does not comply with these terms. 